No 4078

Studia nad Autorytaryzmem i Totalitaryzmem 43, nr 4 Wrocław 2021

https://doi.org/10.19195/2300-7249.43.4.24

\author{
DAGMARA GRUSZECKA \\ ORCID: 0000-0003-3370-7902 \\ Uniwersytet Wrocławski \\ dagmara.gruszecka@uwr.edu.pl
}

\title{
Niemiecka doktryna i judykatura wobec problemu odpowiedzialności karnej ,sprawców zza biurek” — uwagi na tle koncepcji Organisationsherrschaft
}

Slowa kluczowe: prawo karne, ,,sprawcy zza biurek”, doktryna Organisationsherrschaft, zbrodnie międzynarodowe, przypisanie.

\author{
GERMAN DOCTRINE AND JUDICATURE ON THE PROBLEM OF CRIMINAL \\ LIABILITY OF "DESK MURDERERS" - COMMENTS IN THE CONTEXT \\ OF THE ORGANISATIONSHERRSCHAFT CONCEPT
}

\begin{abstract}
The aim of the paper is to present the concept of Claus Roxin's Organisationsherrschaft as an alternative to attributing criminal responsibility for crimes committed by Nazi "desk murderers." This concept arose against the background of criticism, after the trials of Adolf Eichmann and Bohdan Stashynsky, of the particularly low number of convictions in similar cases and the numerous omissions of the entire German justice system. Under West German criminal law, a distinction made between those who order murder and those who commit murder on their own initiative meant that the above-mentioned perpetrators who passed on orders from above could only be found guilty of accessory to murder. The novelty of Roxin's views, however, consisted in an attempt to combine the previous only individualistic perspective of criminal law with the idea of mass, bureaucratic murders. The traditional system of individual attribution of responsibility, as applied for ordinary criminality characterized by the individual commission of single crimes, must be adapted to the needs of collective responsibility, in which the organization (for example, an administrative structure) as a whole serves as the entity upon which attribution of criminal responsibility is based. The first part of the text discusses the main lines of argumentation presented by the West German jurisprudence in cases concerning high-ranking members of the state power apparatus of the Third Reich. At the same time, efforts were made to emphasize the lack of homogeneity of legal solutions presented in national criminal jurisdiction in West Germany and their unacceptable consequences. The second
\end{abstract}


part is devoted to the basic theoretical assumptions of the doctrine of Organisationsherrschaft and its significance for the perception of the boundary between perpetration and participation in German criminal law. The third part briefly presents the contemporary reception of Roxin's thought, as well as the main points of his criticism, indicating, however, how important it was to effectively prosecute decision-makers from the power apparatus of the Third Reich.

Keywords: criminal law, “desk murderer”, doctrine of Organisationsherrschaft, international crimes, attribution.

W okresie powojennym zachodnioniemiecki wymiar sprawiedliwości stanął przed zagadnieniem prowadzenia postępowań w sprawach przestępstw, które pod wieloma względami drastycznie różniły się od obrazu czynów zabronionych, $\mathrm{z}$ jakimi dotąd miały do czynienia zarówno teoria, jak i praktyka prawa karnego. Chodziło mianowicie o zbrodnie, przy których szczególnie zawodne okazywało się tradycyjne nastawienie represji prawnokarnej na wyizolowany podmiot przypisania. Wynikało to z faktu, iż osoby, które mogły być postrzegane jako odpowiedzialne za te zbrodnie, działały w ramach zorganizowanych i zinstytucjonalizowanych jednostek zbiorowych, jakimi były poszczególne struktury urzędnicze III Rzeszy ${ }^{1}$. Z perspektywy czysto karnistycznej, na której koncentrować się będą dalsze uwagi ${ }^{2}$, zasadniczym problemem stała się zatem dwoistość charakteru czynów tak zwanych „sprawców zza biurek" ${ }^{3}$ - z jednej strony kolektywność

1 Ten element kolektywny w postaci wprzęgnięcia w mechanizm zbrodni całego aparatu państwowego oraz scentralizowanej i silnie zbiurokratyzowanej struktury „urzędniczego labiryntu III Rzeszy" jest podkreślany zwłaszcza w refleksji poświęconej ludobójstwu popełnionemu na ludności żydowskiej (wymienić tu trzeba przede wszystkim prace B. Langa, H. Arendt, L. Dawidowicz, Z. Baumana czy Y. Bauera).

2 Celem rozważań jest wyłącznie spojrzenie na ten aspekt skomplikowanej problematyki ścigania sprawców zbrodni nazistowskich w Republice Federalnej Niemiec, który dotyczy prawnokarnej oceny stosowanych formuł jurydycznych. Nie zmienia to świadomości szerokiego spektrum czynników społeczno-politycznych, które odegrały rolę w działaniach wymiaru sprawiedliwości i przełożyły się ostatecznie na niezwykle niską liczbę skazań (co do danych statystycznych zob. szczegółowe studium A. Eichmüller, Die Strafverfolgung von NS-Verbrechen durch westdeutsche Justizbehörden seit 1945. Eine Zahlenbilanz, „Vierteljahreshefte für Zeitgeschichte” 2008, z. 4, s. 621 n.). Jak podaje Eichmüller, na podstawie dostępnych baz danych, zwłaszcza z Centrali w Ludwigsburgu i własnych badań aktowych, w latach 1945-2005 wszczęto 172 tysiące postępowań karnych, z których tylko 14 tysięcy zakończyło się prawomocnymi wyrokami, w tym mniej niż połowa (6500) — wyrokami skazującymi.

3 Posługuję się tym terminem, gdyż wydaje się on najlepiej oddawać — bez konieczności dalszego doprecyzowania - jaki charakter czynów i jaka konkretna kategoria ich sprawców są przedmiotem prowadzonych tu rozważań. Wedle definicji niemieckiego pojęcia Schreibtischtäter chodzi o osoby, ,które planują przestępcze działania i pozwalają je urzeczywistniać innym” (powołuję się na H. Paul, Deutsches Wörterbuch, Berlin 2002, s. 877; K. Krämer, Individuelle und kollektive Zurechnung im Strafrecht, Tübingen 2015, s. 148). Sam termin „sprawca zza biurka” został po raz pierwszy użyty w latach sześćdziesiątych w artykule opublikowanym w „Frankfurter Allgemeine Zeitung" (termin ten jest często przypisywany H. Arendt, która jednak użyła go później 
tych czynów wyrażająca się w całym instytucjonalno-organizacyjnym kontekście ich realizacji, z drugiej - determinowanej indywidualistycznym paradygmatem prawa karnego - konieczność uchwycenia zachowania jednostki, cechującego się dostatecznym stopniem prawnokarnej istotności. Przy tym samo ograniczenie się do jednego $\mathrm{z}$ dwóch wymienionych aspektów: organizacyjnego (a zatem zbiorowego) oraz jednostkowego ani nie dawało pełnego obrazu zaistniałego bezprawia, ani nie zwiększało szans na znalezienie miarodajnej podstawy prawnej ewentualnego skazania ${ }^{4}$.

Ujmując rzecz najprościej: od strony reguł prawnokarnego przypisania odpowiedzialności przy uwikłaniu w układy wieloosobowe w grę wchodziło albo uznanie bezprawności aparatu urzędniczego jako takiego i tym samym przestępnego charakteru uczestnictwa $\mathrm{w}$ nim $^{5}$, albo przypisanie oparte na formach zjawiskowych. To pierwsze pozwalałoby uczynić istotą zarzutów jedynie fakt przynależności jako takiej, bez najmniejszego nawet odniesienia się do całej zbrodniczej działalności poszczególnych osób względem ofiar mordów, tortur, prześladowań, deportacji itp. Należy mieć przy tym świadomość, że inny z kolektywnie zorientowanych czynów zabronionych, czyli ludobójstwo, został wprowadzony do StGB dopiero w połowie lat pięćdziesiątych ${ }^{6}$, a zatem wykorzystanie nowej normy z § 220a StGB do zachowań wcześniejszych musiało zderzyć się z najpoważniejszymi kontrowersjami natury gwarancyjnej. Natomiast druga $\mathrm{z}$ dostępnych opcji wymagała powiązania zindywidualizowanego zachowania danego kandydata do odpowiedzialności, na przykład za zabójstwo, z funkcjonowaniem struktur organizacyjnych w których tkwił, a co więcej — które czynnie współtworzył. Uregulowane w StGB konfiguracje wieloosobowe: sprawstwa (w tym

w wywiadzie prasowym, zaś w związku z procesem Eichmanna posługiwała się raczej określeniem „biurokracja zbrodni”, org. bureaucracy of murder — zob. H. Arendt, Eichmann w Jerozolimie. Rzecz o banalności zła, przeł. A. Szostkiewicz, Kraków 1987).

4 Zob. uwagi C. Roxin, Straftaten im Rahmen organisatorischer Machtapparate, „Goltdammer's Archiv für Strafrecht” 1963, s. 193.

${ }^{5}$ Zgodnie z typizacjami odpowiadającymi rodzimej regulacji art. 258 k.k. — tworzenie grupy przestępczej, związku przestępczego albo tajnego sprzysiężenia (kolejno: § 127-129 StGB).

$6 \S 220$ a StGB został wprowadzony do StGB 22 lutego 1955 roku. W kolejnych ustępach przewidywał on karalność za popełnione $\mathrm{z}$ zamiarem wyniszczenia w całości lub w części grupy narodowej, rasowej, religijnej lub etnicznej jako takiej, umyślne: 1. zabójstwa; 2. spowodowanie poważnego uszczerbku ciała lub zdrowia psychicznego członków grupy; 3. umieszczenie w warunkach życiowych, które doprowadzają do częściowej lub całościowej fizycznej degradacji; 4. stosowanie środków, które mają przynieść wstrzymanie urodzin w obrębie grupy; 5. przymusowe przekazywanie dzieci z jednej grupy członkom innej grupy. Od razu rzuca się w oczy, że tekst przepisu stanowił powtórzenie odpowiednich unormowań Konwencji ONZ w sprawie zapobiegania i karania zbrodni ludobójstwa (uchwalona przez Zgromadzenie Ogólne Narodów Zjednoczonych dnia 9 grudnia 1948 roku, ratyfikowana zgodnie z ustawą z dnia 18 lipca 1950 roku, Dz.U. z 1952 r. Nr 2, poz. 9). Obecnie przepis $\S 220$ a StGB został uchylony na mocy ustawy wprowadzającej w życie przepisy kodeksu karnego międzynarodowego - Gesetz zur Einführung des Völkerstrafgesetzbuches od 26 czerwca 2002 roku (BGBl. I S. 2254), która to zmiana weszła w życie 30 czerwca 2002 roku. 
współsprawstwa), podżegania i pomocnictwa okazywały się jednak istotnie rozmijać ze specyfiką ,zinstytucjonalizowanej działalności przestępczej”, gdyż ten, kto sprawował ogólne funkcje zarządcze czy kierownicze na danym szczeblu, identyfikował się z przestępczymi celami i przez system poleceń zapewniał ich realizację, mógł nawet nie obejmować swoją świadomością konkretnych aktów realizacyjnych. Między nim a ostatecznym bezpośrednim wykonawcą danego czynu zabronionego istniał cały mechanizm urzędniczy złożony z kolejnych poziomów podległych współpracowników.

Tytułem ogólniejszej uwagi warto zaś wskazać, że niezależnie od całej ,jurysprudencji taktycznej"7, instrumentarium prawa karnego nie radzi sobie - do dziś zresztą - $\mathrm{z}$ wieloma problemami stosowania formuł rozszerzania sprawstwa ${ }^{8}$. Podstawowym kierunkiem jego ewolucji było wszak rozwijanie tych właśnie metod i narzędzi dogmatycznych, które zapewnią wyizolowanie zachowania pojedynczego podmiotu w celu zapobieżenia przypadkom „odpowiedzialności zbiorowej” oraz zabezpieczą jednostkę przed groźbą obciążania jej zarzutem sprawstwa w stosunku do czegoś, co leżało już poza granicami jej własnej sfery oddziaływania. $Z$ jednej strony zatem potrzeba zdecydowanego odcięcia się po II wojnie światowej od deprawacji władzy, karania jednostki przez system totalitarny i jego pogardy dla roli i znaczenia indywiduum czyniły tę orientację przeważającą, z drugiej jednak — postawienie przed sądem sprawców wspomnianych wypaczeń, którzy działali przecież nie samodzielnie, lecz w ramach systemu, stało się niemożliwe bez uwzględnienia perspektywy kolektywistycznej.

\section{Zasadnicze kierunki orzecznicze reprezentowane przez zachodnioniemiecką judykaturę przy ocenie zachowań nazistowskich decydentów}

Nawet przy pobieżnej analizie poszczególnych postępowań w sprawach „sprawców zza biurek" musi rzucać się w oczy brak jakiegokolwiek wyraźniejszego schematu orzeczniczego, a nawet wzajemna sprzeczność wielu proponowanych linii argumentacyjnych ${ }^{9}$. O ile w ogóle postępowanie karne mogło być

7 Wedle określenia M. Frommel dostatecznie wyraźnie odzwierciedlającego powojenne nastawienie większości przedstawicieli organów wymiaru sprawiedliwości RFN — eadem, Taktische Jurisprudenz - Die verdeckte Amnestie von NS-Schreibtischtätern 1969 und die Nachwirkung der damaligen Rechtsprechung bis heute, [w:] Gesellschaft und Gerechtigkeit. Festschrift für Hubert Rottleuthner, red. M. Mahlmann, Baden-Baden 2011, s. 458.

${ }^{8}$ Na przykład, gdy zachodzi konieczność znalezienia kryteriów przypisania jednej osobie tego, co fizycznie uczyniła inna osoba lub co w ogóle zostało uczynione w kontekście kolektywnym, a nawet przez jednostkę kolektywną jako taką (otrzymujemy tym samym przegląd problemów od form współdziałania przestępczego po ewentualną odpowiedzialność karną podmiotów zbiorowych).

${ }^{9}$ Por. K. Freudiger, Die juristische Aufarbeitung von NS-Verbrechen, Tübingen 2002, s. 43; G. Werle, Der Holocaust als Gegenstand der bundesdeutschen Strafjustiz, „Neue Juristische Wochenschrift" 1992, z. 40, s. 2529. 
kontynuowane i doprowadzone aż do stadium jurysdykcyjnego ${ }^{10}$, o tyle przy ograniczeniu kwalifikacji prawnej zachowań decydentów ze struktur urzędniczych do pomocnictwa do przestępstwa - o skazaniu lub uniewinnieniu rozstrzygały niejednokrotnie same kwestie dowodowe. Wspomniana forma zjawiskowa $^{11}$ wymagała bowiem wykazania obiektywnego wkładu działalności w powodzenie danego czynu zabronionego. Takiego charakteru nie dopatrzył się sąd przykładowo w sprawie SS-Sturmbannführera i p.o. szefa berlińskiego Gestapo K. Ventera ${ }^{12}$. Ocenił, że samo piastowanie przez niego stanowisk w wysokich strukturach bezpieczeństwa III Rzeszy (Główny Urząd Bezpieczeństwa Rzeszy, Judenreferat), nawet jeśli uwzględnić powszechnie znany charakter tej funkcji i związanych z nią kompetencji, nie wystarczało do uznania go za winnego pomocnictwa do mordów i deportacji ludności żydowskiej:

Oskarżony jako urzędnik administracyjny kierowniczego szczebla i p.o. szefa udzielał pomocy w znaczeniu zupełnie ogólnym, służącej temu, by zapewnić utrzymanie właściwej organizacji Gestapo w Berlinie i funkcjonowanie tego urzędu. Wedle przekonania sądu to zaś nie może być postrzegane jako obiektywna realizacja zachowań pomocnika do przestępstwa kwalifikowanego zabójstwa deportowanych żydowskich mieszkańców Berlina, gdyż nie chodzi w tym przypadku o skonkretyzowane ułatwienie/udzielenie wsparcia do czynu głównego ${ }^{13}$.

Podobne racje, opierające się na zanegowaniu przestępczego charakteru samej generalnej działalności związanej z zajmowanym stanowiskiem, zastosowane zostały już wcześniej między innymi w postępowaniu prowadzonym przeciwko E. Grosse - kierownikowi wydziału Gestapo ${ }^{14}$.

Zdecydowanie najmocniej zaważyła jednak na orzecznictwie akceptacja skrajnej postaci subiektywnej koncepcji rozgraniczania sprawstwa i udziału w cudzym

10 Jak podaje M. Greve (idem, Neuere Forschungen zu NS-Prozessen: Ein Überblick, „Kritische Justiz" 1999, nr 3, s. 473) w latach 1945-1966 przeprowadzonych zostało nieco ponad 600 postępowań. Jeszcze bardziej znaczący wydaje się sam rozkład statystyczny zarzucanych czynów: $36 \%$ postępowań dotyczyło przestępstw popełnionych w końcowej fazie działań wojennych (tak zwane Endphaseverbrechen), 19\% — przestępstw z użyciem przemocy w obozach, 5\% — przestępstw „eutanazji” i 3\% — eksterminacji dokonywanych przez Einsatzgruppen. Szczególnie niewielka była liczba zbrodni sądowych (3\%), prawie bez wyjątku zresztą zakończonych ekskulpacją sprawców, zaś przestępstwa „sprawców zza biurek” stanowiły jedynie 1\% ogółu czynów. Dalsze wyobrażenie o nastawieniu wymiaru sprawiedliwości daje też rozkład kar. Od czasu powstania RFN na karę dożywotniego pozbawienia wolności skazano tylko 157 oskarżonych; wszyscy inni otrzymywali kary pozbawienia wolności, najczęściej w dolnym ich wymiarze, a nawet nadzwyczajnie złagodzone.

11 Stosownie do $\S 27$ StGB pomocnictwo ma miejsce wtedy, gdy ktoś świadomie udziela sprawcy wsparcia w popełnieniu przestępstwa.

12 Wyrok Landesgericht (LG) w Berlinie z 7 kwietnia 1971 roku, 1 Ks 2/69, JNS Bd. XXXV, Lfd. nr 754, s. 321. Zarzuty aktu oskarżenia dotyczyły pomocnictwa do co najmniej 38 przypadków mordów dokonanych na obywatelach miasta Berlin żydowskiego pochodzenia.

$13 \mathrm{Z}$ uzasadnienia wyroku LG w Berlinie z 7 kwietnia 1971 roku, 1 Ks 2/69, JNS Bd. XXXV, Lfd. nr 754, s. 370.

14 Zob. K. Krämmer, op. cit., s. 154; sprawa zresztą zakończyła się umorzeniem postępowania. 
przestępstwie ${ }^{15}$. Szczególnie interesująca wydaje się ewolucja nawiązującej do niej argumentacji. O ile bowiem $\mathrm{H}$. Baab ${ }^{16}$, referent we frankfurckim oddziale Gestapo, został skazany za wielokrotne współsprawstwo morderstw w związku z udziałem w przygotowywaniu list deportacyjnych do obozów koncentracyjnych, to w późniejszym o 20 lat postępowaniu w sprawie F. Wöhrna ${ }^{17}$, również referenta - choć tym razem w Judenreferat RSHA, zasadniczo zbieżny stan faktyczny stał się podstawą wyroku skazującego wyłącznie za pomocnictwo. W obu postępowaniach centralnym przedmiotem badania była treść woli oskarżonych, przy czym Baab z uwagi na podzielanie rasistowskiego światopoglądu oraz identyfikowanie się z celami i metodami działania nazistowskiego reżimu miał tym samym wykazać własny interes w zarzucanych mu zabójstwach, a zatem miał działać cum animo auctoris. „Interes ten może bowiem polegać również na podzielanych przez sprawce ideologicznych zapatrywaniach, które czynią przestępczy skutek wartym starań"18. Tożsama treść psychicznego nastawienia Wöhrna skutkowała jednak stwierdzeniem przez sąd, że samo przyjęcie antysemickich postaw przełożonych jako własnych nie wystarcza do wykreowania sprawstwa, to bowiem „od owych przełożonych wypływała inicjatywa kolejnych zbrodni" ${ }^{\text {"19 }}$, a zatem to ich jedynie można by było za sprawstwo skazać.

$\mathrm{Z}$ czasem powszechne wskazywanie jako głównych sprawców ludzi z grona najwyższych oficjeli III Rzeszy (Himmler czy Goebbels) oraz samego Hitlera pozwoliło traktować zachowania reszty co najwyżej jako pomocnictwo. Przełomową rolę odegrał tu wyrok w sprawie B.N. Staszyńskiego ${ }^{20}$. Rzecz jasna, Staszyński był agentem KGB, lecz judykat Trybunału Federalnego (BGH) w jego sprawie znalazł szeroki odzew w piśmiennictwie i miał poważne konsekwencje właśnie dla ścigania zbrodniarzy nazistowskich. Jako bezpośredni wykonawca zabójstw

15 Podobnie jak w rodzimej nauce prawa karnego, o tym, czy uznać daną osobę za sprawce (współsprawcę), czy jedynie za pomocnika, można rozstrzygać na podstawie kryterium subiektywnego, to jest ustalenia, czy działał on cum animo auctoris, we własnym imieniu i traktując czyn, w którym miał udział, jako czyn własny, czy też działał cum animo socii, postrzegając swoją rolę jedynie jako podrzędną i polegającą na uczestniczeniu w czynie cudzym - zob. J. Giezek, [w:] Prawo karne materialne. Czesść ogólna i szczególna, red. M. Bojarski, Warszawa 2020, s. 282; szerzej zob. P. Kardas, Teoretyczne podstawy odpowiedzialności karnej za przestepne wspótdziałanie, Kraków 2001, s. 478 n.

16 Wyrok LG we Frankfurcie nad Menem z 5 kwietnia 1950 roku, 51 Ks 1/50, JNS Bd. VI, Lfd. nr 207, s. 371.

17 Wyrok LG w Berlinie z 13 października 1971 roku, 1 Ks 1/69, JNS Bd. XXXV, Lfd. nr 753a oraz wyrok LG w Berlinie z 13 października 1969 roku, 1 Ks 1/69, JNS Bd. XXXV, Lfd. nr 753 b, s. 275.

18 Wyrok LG we Frankfurcie nad Menem z 5 kwietnia 1950 roku, 51 Ks 1/50, JNS Bd. VI, Lfd. nr 207, s. 389.

19 Wyrok LG w Berlinie z 13 października 1969 roku, 1 Ks 1/69, JNS Bd. XXXV, Lfd. nr 753b, s. 309. Nawet „nadzwyczajna gorliwość”, z jaką wykonywał swoje obowiązki, nie przemawiała za uznaniem jego interesu w czynie jako własnego.

${ }^{20}$ Wyrok BGH z 19 października 1962 roku, 9 StE 4/62, BGHSt 18, 87. 
politycznych Staszyński został skazany jedynie za pomocnictwo do kwalifikowanego zabójstwa. Aby tego rodzaju orzeczenie w ogóle było możliwe, trybunał posłużył się karkołomnym wywodem bazującym na właściwym dla koncepcji subiektywnej twierdzeniu, że "sprawcą jest ten, kto chce czynu jako swojego". Wykazał, iż to szef KGB, a nie Staszyński, obejmował zlecone zabójstwa własną wolą sprawczą, realizujący rozkazy agent miał zaś jedynie „wolę pomocnika”. Dość szybko powyższe okazało się wygodną ścieżką argumentacyjną dla byłych nazistowskich urzędników niższych poziomów hierarchii, którzy mogli bronić się nieweryfikowalnym zasadniczo twierdzeniem, że nie podzielali bezkrytycznie poglądów głównych sprawców (Hitler itp.) i nie chcieli tychże czynów, a przynajmniej nie jako własnych. Cała wskazana linia orzecznicza zyskała zresztą dość szydercze miano „Gehilfenjudikatur”, co można by tłumaczyć dwojako, nie tylko w nawiązaniu do pomocniczości w rozumieniu zastosowanej normatywnej konstrukcji współdziałania ${ }^{21}$.

\section{Nowatorskość koncepcji Organisationsherrschaft C. Roxina}

Jak zatem starano się wskazać, zarówno doktryna, jak i praktyka sądowa RFN nie były w stanie nie tylko skutecznie sprostać potrzebie ścigania i ukarania osób, które aktywnie uczestniczyły w funkcjonowaniu nazistowskiego aparatu przymusu. Poza ich zasięgiem znajdowało się nawet wypracowanie w miarę konsekwentnych oraz funkcjonalnych rozwiązań teoretycznoprawnych. Dopiero jednak po jerozolimskim procesie A. Eichmanna oraz wyroku w sprawie Staszyńskiego w piśmiennictwie karnistycznym zaczęły pojawiać się kategoryczne głosy krytykujące dotychczas wykorzystywane koncepcje, przede wszystkim zaś mocno umiarkowaną skuteczność, z jaką pozwalały one na osądzenie decydentów o niewątpliwej nazistowskiej przeszłości ${ }^{22}$. Na tym tle propozycja rozszerzenia figury sprawstwa o tak zwane sprawstwo organizacyjne - zgłoszona przez C. Roxina ${ }^{23}$

21 Por. M. Greve, Der justitielle und rechtspolitische Umgang mit den NS-Gewaltverbrechen in den sechziger Jahren, Frankfurt am Main 2001, s. 145 n.

22 Co do tego swoistego ,przełomu” w naukowej debacie nad karaniem sprawców z szeroko rozumianego aparatu urzędniczego III Rzeszy — szerzej zob. ibidem, s. 181 n. Zresztą autor niezwykle interesująco przedstawia również same początki systematycznego ścigania zbrodni nazistowskich, począwszy od powstania Centrali Badań Zbrodni Narodowosocjalistycznych (Zentrale Stelle) w Ludwigsburgu w 1958 roku i społeczno-politycznej reakcji na ten fakt. Wskazuje między innymi na rolę nacisków z zagranicy, które odegrały ważną rolę w decyzji Konferencji Ministrów Sprawiedliwości w Bad Harzburg (październik 1958 roku), oraz na konieczność odpowiedzi na wschodnioniemiecką „Braunbuch”. Właściwości Centrali ograniczały się jednak tylko do przestępstw popełnionych wówczas poza RFN, a realne efekty założeń pozostały marginalne — zob. ibidem, s. 40 n.

23 Po raz pierwszy C. Roxin ujął ją w przywoływanej już pracy Straftaten im Rahmen organisatorischer Machtapparate z 1963 roku, a następnie w swojej habilitacji z tego samego roku: Täter- 
- miała wreszcie dostarczyć organom wymiaru sprawiedliwości efektywnego, a zarazem niebudzącego poważniejszych wątpliwości legitymacyjnych narzędzia. Narzędzia mającego zresztą mocno tkwić w dotychczasowej i obowiązującej dogmatyce form współdziałania przestępnego, tak aby z góry przeciwdziałać argumentom odnoszącym się zarówno do zakazu analogii na niekorzyść, jak i do zakazu retroaktywności przepisów statuujących odpowiedzialność karną.

Przykłady postępowań prowadzonych przeciwko członkom nazistowskiego aparatu przemocy dobitnie wykazały, na jakie bezdroża prowadzą koncepcja subiektywna i formuła pomocnictwa. Jeśli wszakże odrzucić wspomniane, wobec zamkniętego katalogu, postaci współdziałania przestępnego, to jedynym jurydycznie dopuszczalnym rozwiązaniem w przypadku „sprawców zza biurek” stawało się postawienie im zarzutów opartych na konstrukcji sprawstwa pośredniego (mittelbare Täterschaft) ${ }^{24}$. Rzecz jednak w tym, że wedle powszechnej wykładni bazującej dotąd jedynie na układach pospolitej przestępczości indywidualnej sprawca pośredni nie mógł „wykorzystać” bezpośredniego wykonawcy, jeżeli ten byłby w pełni odpowiedzialny za swoje czyny. Wówczas bowiem to ten drugi przejmowałby — w ramach autonomii decyzyjnej — sprawczość. Punktem wyjścia dla idei Roxina stała się jednak obserwacja, że w układach zinstytucjonalizowanego, skomplikowanego łańcucha współdziałania — tak zresztą, jak miało to miejsce w sprawie Eichmanna - pośredni sprawcy opierają się na specyficznym sposobie działania całego wspierającego ich i pozostającego do ich dyspozycji aparatu. Taka organizacja funkcjonowała niejako automatycznie, bez

schaft und Tatherrschaft. Jak sam przyznaje: „O tym, że temat ten był wówczas jeszcze traktowany jako kwestia polityczna, świadczy fakt, że czasopismo »Juristen Zeitung « odmówiło jego druku; był to jedyny raz w mojej karierze prawniczej, gdy taka rzecz przydarzyła mi się jako autorowi” idem, Organisationsherrschaft und Tatentschlossenheit, ,Zeitschrift für Internationale Strafrechtsdogmatik" 2006, z. 7, s. 293. Warto przy tym zaznaczyć, że w swoich zamierzeniach podobna, choć oparta na sprawstwie pośrednim, konstrukcja została również, nieco tylko później, przedstawiona przez F.-Ch. Schroedera, który wskazywał, że w organizacjach decydenci określani przez niego jako „sprawcy zza sprawców” pozostają w pełni świadomi tego, że przy wdrażaniu podjętych przez nich decyzji w każdym czasie dysponują kolejnymi szczeblami dalszych wykonawców aż po wykonawców bezpośrednich: „Takie wykorzystanie ma miejsce, gdy realizacja zamiaru zależy tylko od tego jednego warunku, który stwarza faktyczny sprawca (Hintermann). Wraz ze świadomością zdecydowanej postawy bezpośrednich wykonawców zanika zaś - typowa dla jedynie współdziałającego - niepewność powodzenia całej akcji, konieczności podporządkowania się ostatecznej decyzji innej osoby"; idem, Täter hinter dem Täter. Ein Beitrag zur Lehre von der mittelbaren Täterschaft, Berlin 1965, s. $166 \mathrm{n}$.

${ }^{24}$ Sprawstwo pośrednie to układ, w którym jedna osoba (Hintermann) posługuje się drugą (Tatmittler - sprawca bezpośredni) jako narzędziem swojej woli. Co do zasady, ten kto jedynie inicjuje czy wspiera akcję przestępczą, ale własnoręcznie nie realizuje znamion danego przestępstwa rodzajowego, jest jedynie podżegaczem (względnie ma w niej udział jako pomocnik). Jeżeli jednak to on, a nie „pośrednik”, w całości decyduje o jej przebiegu, to należy jego „wkład” uznać za na tyle istotny, by przesądzał on o sprawstwie. C. Roxin, Strafrecht. Allgemeiner Teil. t. 2. Besondere Erscheinungsformen der Straftat, München 2003, § 25, s. 22-23. 
względu na indywidualne osoby wykonujące jej cele ${ }^{25}$. Przy powyższym obrazie aparatu władzy wyobrażalne stały się trzy, a nie dwa sposoby zrealizowania układu osobowego charakteryzującego sprawstwo pośrednie: osoba kierująca akcją (Hintermann) mogła mianowicie nie tylko zmusić wykonawcę do działania lub wprowadzić w błąd co do okoliczności decydującej o sprawstwie, to znaczy wprowadzić go do akcji jedynie w charakterze ślepego czynnika kauzalnego, lecz także dowolnie zastępować go innym wykonawcą. Z tego względu zasadniczego znaczenia nabrała figura „wymienności” (Fungibilität) ${ }^{26}$, odnosząca się do nieograniczonej w praktyce zastępowalności każdorazowego bezpośredniego wykonawcy (lub któregokolwiek z wykonawców stojących niżej w hierarchii od decydenta i tworzących wspomniany „łańcuch sprawczy”). W razie gdyby jedno z takich „ogniw” odpowiedzialnych za bezpośrednie urzeczywistnienie przestępczych planów odmówiło wykonania scedowanych na nie zadań, byłoby ono wymieniane na inne; co więcej - natychmiast i bez jakiejkolwiek szkody dla realizacji całego zbrodniczego przedsięwzięcia ${ }^{27}$. Do dyspozycji decydenta pozostaje bowiem wielu „podwykonawców”. Decydent posługuje się nawet nie tyle nimi, ile właśnie całym ,aparatem”, którego poszczególnych członków nie musi wcale znać ${ }^{28}$. Jak wprost stwierdza Roxin, taki ,wymienny trybik w mechanizmie aparatu władczego" nie jest w stanie uniknąć realizacji rozkazu, a tym samym to nie do niego należy decyzja o tym, czy dany czyn ma mieć miejsce. Rozstrzygają o tym jego przełożeni i choć daleko im do wypełnienia „własnymi rękami” któregokolwiek ze znamion konkretnego typu czynu zabronionego, na którego popełnianie nastawiona jest organizacja, to nie ma ryzyka, że bezpośredni wykonawcy zachowają się w sposób sprzeczny z ich wolą. Wyłączność kompetencji decyzyjnych powoduje, że to przy przełożonych pozostaje władztwo nad czynem (Tatherrschaft) ${ }^{29}$, a zatem ten element, który w systematyce niemieckich form

25 Zob. C. Roxin, Organisationsherrschaft..., s. 293.

26 C. Roxin, Straftaten..., s. 201.

27 „Głębsze spojrzenie pokazuje, że ta odmienna ocena opiera się na specyfice sposobu oddziaływania aparatu, który pozostawiony został do dyspozycji sprawców - decydentów (Hintermänner). [...] Należy jedynie mieć przed oczami ten — w żadnym razie nie jedynie teoretyczny — kazus, że w reżimie będącym dyktaturą władza państwowa rozbudowuje aparat służący likwidacji dowolnych osób lub grup ludności. Jeżeli w tym stanie faktycznym zajmujący w strukturze organizacyjnej stanowisko dowódcze - mówiąc metaforycznie - naciśnie guzik i wyrazi polecenie zabójstwa, to może on polegać na tym, że skutek zostanie zrealizowany i to nawet bez potrzeby jego osobistego zwracania się do bezpośredniego wykonawcy czy poznania go. Nie ma też konieczności, by sięgał on po środki w rodzaju przymusu czy wprowadzenia w błąd. Wie bowiem, że jeżeli przy wielości organów zaangażowanych w dojście do skutku przestępstwa choć jeden nie wykona swojego zadania, w jego miejsce wejdzie inny, bez naruszenia realizacji całego planu". Ibidem, s. 203. Zob. też idem, Täterschaft und Tatherrschaft, Berlin-Boston 2019, s. 245.

28 C. Roxin, Strafrecht..., t. 2, s. 47.

29 „Kto realizuje czyn własnoręcznie, jest sprawcą. Kto jednakże w aparacie organizacyjnym stanowi taką jego część, że na jakimkolwiek stanowisku jest uprawniony do wydawania poleceń 
współdziałania przestępnego charakteryzuje sprawstwo sensu stricto $\mathrm{w}$ przeciwieństwie do jedynie udziału w cudzym przestępstwie ${ }^{30}$.

W opisywanej przez Roxina strukturze fakt zaistnienia przestępstwa jest zdeterminowany już w momencie wydania polecenia dalszym szczeblom wykonawczym. Hierarchicznie ustrukturyzowany aparat władzy, który oderwał się od prawa i praworządności ${ }^{31}$, określa zewnętrzne warunki stosowania konstrukcji sprawstwa, wynikające właśnie z władzy organizacyjnej. Panowanie nad przebiegiem akcji przestępczej ma tu zatem postać tak zwanego Willensherrschaft $t^{32}$ — podobnie jak przy innych przypadkach popełnienia przez kogoś innego czynu zabronionego. „Kto bowiem dyryguje innymi w ramach aparatu władzy, zapewnia sobie uniezależnienie swoich poleceń od indywidualnej osoby wykonawcy. Ten ostatni przykład dotyczy zaś sprawstwa pośredniego na mocy sprawstwa organizacyjnego" ${ }^{33}$. Z dwoma znanymi konfiguracjami sprawstwa pośredniego - kreowanego właśnie przez warunek całkowitej zależności i posłuchu wykorzystywanego ludzkiego „narzędzia” - to jest zapewnienia sobie realizacji tego warunku na skutek posłużenia się przymusem (Willensherrschaft kraft Nötigung) oraz wykorzystania błędu lub innej niezdolności do przypisania winy (Willensherrschaft kraft Irrtums), zrównana zostaje trzecia - Willensherrschaft kraft organisatorischer Machtapparate. Jest przy tym szczególne, że choć podlegający decydentowi bezpośredni wykonawcy są postrzegani czysto instrumentalnie, jako elementy instytucjonalnej machiny, to jednak - w przeciwieństwie do zapośredniczenia sprawstwa $\mathrm{w}$ działaniach osób nieletnich czy niepoczytalnych - nie wyzbywają się oni swojego

podwładnym, również będzie sprawcą, jeżeli realizuje swoje uprawnienia dla popełnienia czynów karalnych". Idem, Straftaten..., s. 203.

${ }^{30}$ Zob. obszernie o teorii udziału w cudzym przestępstwie i różnicach między regulacją polską a niemiecką P. Kardas, op. cit., s. 204 n.

31 Założenie, że cała organizacja musi być postrzegana jako bezprawna, jest wielokrotnie akcentowane przez Roxina, co zresztą ma na celu polemikę z modelem ekskulpacji na podstawie nierozpoznawalności bezprawności. Dlatego daje on wyraz przekonaniu, ,że »sprawstwo organizacyjne« zakłada istnienie aparatu, który realizując zbrodnie, oderwał się od prawa jako całości, tak że ta forma nie może zaistnieć we wspólnocie respektującej założenia państwa prawa”. C. Roxin, Täterschaft..., s. 252; idem, Organisationsherrschaft..., s. 293.

32 Powyższe stwierdzenie wymaga pewnego komentarza odnoszącego się do roxinowskiego ujęcia form współdziałania przestępnego, określonych w § 25 StGB (sprawstwo - Täterschaft), który to przepis stanowi, że „1) Każdy, kto popełnia przestępstwo sam lub za pośrednictwem kogoś innego, podlega karze jako sprawca. (2) Jeżeli przestępstwo popełnia kilka osób wspólnie, każda z nich podlega karze jako sprawca (współsprawca)". W przypadku jednosprawstwa o władztwie nad czynem decyduje samodzielna realizacja znamion czynu zabronionego (Handlungsherrschaft), przy współsprawstwie - realizacja całości znamion wraz z inną osobą (funktionale Tatherrschaft). $\mathrm{W}$ odniesieniu do drugiego członu alternatywy w ustępie pierwszym, wskazującym na tak zwaną figurę sprawstwa pośredniego, władztwo nad czynem, pozwalające na kwalifikację współdziałającego jako głównego sprawcy, a nie jedynie podżegacza czy pomocnika, może przybrać jedynie postać tak zwanego Willensherschaft. Szerzej zob. C. Roxin, Strafrecht..., t. 2, s. 22-23.

33 C. Roxin, Zu neusten Diskussion über die Organisationsherrschaft, „Goltdammer's Archiv für Strafrecht” 2012, s. 395. 
statusu sprawcy tylko dlatego, że wprowadzona zostaje osoba przełożonego, również sprawcy. Taką konfigurację, niespotykaną dotąd w niemieckiej dogmatyce, uznaje Roxin za logicznie i teleologicznie dopuszczalną, gdyż sprawstwo każdej z osób opiera się na odmiennych przesłankach: sprawca bezpośredni wykonuje czyn „własnoręcznie”, podczas gdy „sprawca zza biurka” jest tu sprawcą pośrednim z uwagi na „kontrolę i sterowanie aparatem organizacyjnym”34. W rezultacie ,ten, kto umyślnie i niezmuszony samodzielnie wykonuje czyn, jest zawsze sprawcą. Tak też musi pozostać, również w przypadku tych rodzajów czynów, o których mowa" ${ }^{35}$. Zarazem nie istnieją podstawy, by decydenta zepchnąć jedynie do niesprawczej roli podżegacza. Jak zauważa Roxin:

Wysoki urzędnik, do którego właściwości należała organizacja mordu na ludności żydowskiej, czy członek służb specjalnych panują nad wystąpieniem skutku w zupełnie odmienny sposób od zwykłego podżegacza. Nikt nie waha się przyznać, że zleceniodawcy zajmują w całym przebiegu zdarzenia miejsce centralne, którego nie sposób porównywać z nakłaniającym w układach „konwencjonalnej” przestępczości ${ }^{36}$.

\section{Znaczenie ujęcia Roxina i recepcja jego poglądów}

Koncepcja Roxina odbiła się szerokim echem w literaturze, gdzie zasadniczo zgodnie $^{37}$ uznawano jej użyteczność w zwalczaniu zaniechań wymiaru sprawiedliwości w ściganiu nazistowskich decydentów. Podkreślano zwłaszcza adekwatność w odzwierciedleniu rozkładu władzy w zbiurokratyzowanych strukturach pozwalającą uczynić centralną figurą faktycznie odpowiedzialnych w miejsce bezpośrednich wykonawców, będących w istocie jedynie ostatnimi ogniwami

34 C. Roxin, Strafrecht..., t. 2, s. 47; zob. też K. Krämer, op. cit., s. 163.

35 C. Roxin, Straftaten..., s. 197.

36 Ibidem, s. 200.

37 Zob. między innymi: K. Amelung, Zum Verantwortungsmaßstab bei der mittelbaren Täterschaft durch Beherrschung eines nicht verantwortlichen Selbstschädigers, [w:] Bausteine des europäischen Strafrechts. Coimbra Symposium für Claus Roxin, red. B. Schünemann, J. de Figueiredo Dias, Köln 1995, s. 252; W. Bottke, Die Struktur von Täterschaft bei aktiver Begehung und Unterlassung als Baustein eines gemeineuropäischen Strafrechtssystems, [w:] Bausteine..., s. 235 n.; R.D. Herzberg, Täterschaft und Teilnahme, München 1977, s. 42; G. Küpper, Zur Abgrenzung der Täterschaftsformen, „Goltdammer“s Archiv für Strafrecht” 1998, s. 519 n.; T. Rotsch, Anmerkung zu BGH 1 StR 453/02, „Juristische Rundschau” 2004, nr 6, s. 248 n.; E.-J. Lampe, Systemunrecht und Unrechtssysteme, „Zeitschrift für die gesamte Strafrechtswissenschaft” 106, 1994, nr 4, s. 683; G. Werle, op. cit., s. 2529; U. Ebert, Strafrechtliche Bewältigung des SED-Unrechts zwischen Politik, Strafrecht und Verfassungsrecht, [w:] Festschrift für Ernst-Walter Hanack zum 70. Geburtstag am 30. August 1999, red. U. Ebert et al., Berlin 1999, s. 533 n.; P. Hünerfeld, Mittelbare Täterschaft und Anstiftung im Kriminalstrafrecht der Bundesrepublik Deutschland, ,Zeitschrift für die gesamte Strafrechtswissenschaft" 99, 1987, nr 2, s. 244; U. Schulz, Die mittelbare Täterschaft kraft Organisationsherrschaft - eine notwendige Rechtsfortbildung?, „Juristische Schulung” 1997, s. 109 n.; K. Krämer, op. cit., s. 164; W. Schild, Täterschaft als Tatherrschaft, Berlin-New York 1994, s. 10 n. 
w łańcuchu delegowania przestępczych zadań ${ }^{38}$. Warto przy tym dodać, że odejście od ujmowania zachowań sprawczych jedynie w ramach, rodzącej obiekcje już nawet na poziomie intuicyjnym, formy pomocnictwa stało się wkrótce szczególnie istotne $\mathrm{z}$ uwagi na wprowadzone zmiany legislacyjne ${ }^{39}$. Za najpełniejsze docenienie trafności propozycji należy jednak uznać trwałe miejsce, jakie znalazła ona $\mathrm{w}$ regulacjach prawa karnego międzynarodowego ${ }^{40}$.

Ta - jak na tak ryzykowną koncepcję naukową i tak długo trwająca — przychylność doktryny jest obecnie częściowo równoważona głosami polemicznymi, o których choćby dla zachowania rzetelności należy wspomnieć. Podstawowe punkty zgłaszanych wątpliwości odnoszą się, generalnie rzecz ujmując, do zacierania granic między sprawstwem a udziałem w cudzym przestępstwie, zwłaszcza w stosunku do niesprawczej formy podżegania oraz stawiania kryminalnopolitycznej potrzeby nad czystość kryteriów dogmatycznych ${ }^{41}$. Kontestowana jest również figura wymienności jako zbyt idealistyczna i zderzająca się z rzeczywistością wielu układów organizacyjnych, w których możliwość zamiany jednego ludzkiego ogniwa wykonawczego na inne jest ograniczona, a nawet niemożliwa. To sprawia, że zdecydowanie osłabione zostaje kryterium całkowitej nieistotności tożsamości

38 Można spotkać poglądy, że — na poziomie sprawstwa — równorzędny status wykonawców powinien być jednak różnicowany na płaszczyźnie winy przez przyjęcie okoliczności ją umniejszających. K. Krämer, op. cit., s. 164.

39 Jedną z poważniejszych stricte procesowych przeszkód w osądzaniu sprawców zbrodni z okresu narodowego socjalizmu stała się nowelizacja w 1968 roku przepisu $\S 50$ ust. 2 StGB, wprowadzająca przedawnienie pomocnictwa do niektórych czynów zabronionych, w tym zabójstwa w typie podstawowym. Od tego momentu pozostawało zatem wyłącznie udowodnienie oskarżonym, że w czasie czynu na przykład działali z niskich pobudek (pomocnictwo do typu kwalifikowanego, to jest: morderstwa, wedle terminologii StGB), co w praktyce przekładało się na falę umorzeń. Szerzej zob. M. Greve, Der justitielle..., s. 349 n.; idem, Neuere Forschungen..., s. 472 n.; A. Rückerl, NS-Verbrechen vor Gericht. Versuch einer Vergangenheitsbewältigung, Heidelberg 1982, s. 190 n.; M. Frommel, op. cit., s. 458 n.

40 Art. 25 ust. 3, lit. a Rzymskiego Statutu Międzynarodowego Trybunału Karnego (sporządzonego w Rzymie 17 lipca 1998 roku, Dz.U. z 2003 Nr 78, poz. 708) stanowi wprost, że „Odpowiedzialności karnej i karze za zbrodnie objęte jurysdykcją Trybunału podlega na podstawie niniejszego statutu osoba, która: (a) popełnia taką zbrodnię [...] za pośrednictwem innej osoby bez względu na to, czy ta inna osoba ponosi odpowiedzialność karną". Zob. też co do wykorzystania koncepcji w orzecznictwie MTK interesujące uwagi: C. Roxin, Zu neusten..., s. 397 n.; K. Ambos, Command responsibility and Organisationsherrschaft: Ways of attributing international crimes to the 'most responsible', [w:] System Criminality in International Law, red. A. Nollkaemper, H. van der Wilt, Cambridge 2009, s. 127 n. oraz wskazywana tam literatura.

41 Tak - dostrzegając niebezpieczeństwo zwłaszcza nadmiernego rozszerzania granic odpowiedzialności karnej i dowolności interpretacyjnej - J. Brammsen, S. Apel, Anstiftung oder Täterschaft? „Organisationsherrschaft” in Wirtschaftsunternehmen, „Zeitschrift für das Juristische Studium" 2008, z. 3, s. 261; R. Bloy, Grenzen der Täterschaft bei fremdhändiger Tatausführung, „Goltdammer's Archiv für Strafrecht” 1996, s. 439; przede wszystkim zaś w swoim monograficznym opracowaniu tematyki Organisationsherrschaft - C. Urban, Mittelbare Täterschaft kraft Organisationsherrschaft: eine Studie zu Konzeption und Anwendbarkeit, insbesondere im Hinblick auf Wirtschaftsunternehmen, Göttingen 2004, s. 27 n., s. 134 n. 
sprawcy bezpośredniego i pewności realizacji akcji po stronie decydenta, na którym bazuje sprawstwo ${ }^{42}$. Przywoływana jest także kolizja z zasadą koincydencji czynu i winy ${ }^{43}$, a wreszcie sięga się po argument zawyżonych wymogów co do świadomości bezprawności działania sprawców, którzy przez dłuższy czas pozostawali pod oddziaływaniem ,państwa bezprawia” (Unrechtsstaat) i otrzymywali rozkazy sprzeczne $\mathrm{z}$ istotą prawa ${ }^{44}$. Większość tych racji wydaje się jednak w pełni uzasadniona jedynie na płaszczyźnie mikroprzestępczości, nie zaś w kontekście przestępstw w skali makro - zbrodni popełnianych w ramach aparatu państwowego ${ }^{45}$.

\section{Zamiast konkluzji}

Z niezwykle szerokim zainteresowaniem nauki drastycznie wręcz kontrastowało konsekwentne ignorowanie koncepcji przez (zachodnio)niemieckie orzecznictwo, które do lat dziewięćdziesiątych ani razu nawet nie wspomniało o niej w uzasadnieniach orzeczeń zapadłych w sprawach „sprawców zza biurek" ${ }^{46}$. Na marginesie zaś egzemplarza „Goltdammer's Archiv” z pierwszym artykułem Roxina, przechowywanego w bibliotece uniwersyteckiej w Getyndze, z którego korzystała autorka, dało się dostrzec zwłaszcza jedną uwagę, skreśloną ołówkiem, ręką ćwiczoną jeszcze w kaligrafii. Brzmiała ona: ,, utopisch”, czego chyba thumaczyć nie trzeba.

\section{Bibliografia}

Ambos K., Command responsibility and Organisationsherrschaft: Ways of attributing international crimes to the 'most responsible', [w:] System Criminality in International Law, red. A. Nollkaemper, H. van der Wilt, Cambridge 2009.

42 T. Rotsch, Tatherrschaft kraft Organisationsherrschaft?, ,Zeitschrift für die gesamte Strafrechtswissenschaft” 112, 2000, nr 3, s. 528; idem, Neues zur Organisationsherrschaft, ,Neue Zeitschrift für Strafrecht” 2005, nr 1, s. 13 n.; N. Bosch, Organisationsverschulden in Unternehmen, Baden-Baden 2002, s. 236; U. Murmann, Tatherrschaft kraft Weisungsmacht, „Goltdammer‘s Archiv für Strafrecht” 1996, s. 273; zob. też odpowiedź Roxina - C. Roxin, Strafrecht..., t. 2, s. 49 n.

43 T. Rotsch, Tatherrschaft..., s. 561.

44 J. Brammsen, S. Apel, op. cit., s. 261; T. Rotsch, Tatherrschaft..., s. 533.

45 Tak też K. Krämer, op.cit., s. 164. Dotyczą one też często specyficznej problematyki nowego obszaru szerokiej adaptacji koncepcji Roxina w ostatnich latach, jakim jest odpowiedzialność gospodarczych podmiotów zbiorowych, zob. między innymi T. Rotsch, Die Rechtsfigur des Täters hinter dem Täter bei der Begehung von Straftaten im Rahmen organisatorischer Machtapparate und ihre Übertragbarkeit auf wirtschaftliche Organisationsstrukturen, „Neue Zeitschrift für Strafrecht" 1998, z. 10, s. 491.

${ }^{46}$ Co gorzko zauważa zresztą sam Roxin - C. Roxin, Strafrecht ..., t. 2, s. 49. Zmianą był dopiero wyrok BGH z 26 lipca 1994, 5 StR 98/94, BGHSt 40, 218; skądinąd dotyczący funkcjonariuszy aparatu byłego DDR — szerzej C. Roxin, Organisationsherrschaft..., s. 293; zob też K. Ambos, Tatherrschaft durch Willensherrschaft kraft organisatorischer Machtapparate - Eine kritische Bestandsaufnahme und weiterführende Ansätze, ,Goltdammer's Archiv für Strafrecht” 1998, s. 227 n. 
Ambos K., Tatherrschaft durch Willensherrschaft kraft organisatorischer Machtapparate - Eine kritische Bestandsaufnahme und weiterführende Ansätze, „Goltdammer's Archiv für Strafrecht" 1998.

Amelung K., Zum Verantwortungsmaßstab bei der mittelbaren Täterschaft durch Beherrschung eines nicht verantwortlichen Selbstschädigers, [w:] Bausteine des europäischen Strafrechts. Coimbra Symposium für Claus Roxin, red. B. Schünemann, J. de Figueiredo Dias, Köln 1995.

Arendt H., Eichmann w Jerozolimie. Rzecz o banalności zła, przeł. A. Szostkiewicz, Kraków 1987.

Bloy R., Grenzen der Täterschaft bei fremdhändiger Tatausführung, „Goltdammer‘s Archiv für Strafrecht" 1996.

Bosch N., Organisationsverschulden in Unternehmen, Baden-Baden 2002.

Bottke W., Die Struktur von Täterschaft bei aktiver Begehung und Unterlassung als Baustein eines gemeineuropäischen Strafrechtssystems, [w:] Bausteine des europäischen Strafrechts. Coimbra Symposium für Claus Roxin, red. B. Schünemann, J. de Figueiredo Dias, Köln 1995.

Brammsen J., Apel S., Anstiftung oder Täterschaft? „, Organisationsherrschaft” in Wirtschaftsunternehmen, „Zeitschrift für das Juristische Studium” 3, 2008.

Ebert U., Strafrechtliche Bewältigung des SED-Unrechts zwischen Politik, Strafrecht und Verfassungsrecht, [w:] Festschrift für Ernst-Walter Hanack zum 70. Geburtstag am 30. August 1999, red. U. Ebert et al., Berlin 1999.

Eichmüller A., Die Strafverfolgung von NS-Verbrechen durch westdeutsche Justizbehörden seit 1945. Eine Zahlenbilanz, „Vierteljahreshefte für Zeitgeschichte” 2008, z. 4.

Freudiger K., Die juristische Aufarbeitung von NS-Verbrechen, Tübingen 2002.

Frommel M., Taktische Jurisprudenz — Die verdeckte Amnestie von NS-Schreibtischtätern 1969 und die Nachwirkung der damaligen Rechtsprechung bis heute, [w:] Gesellschaft und Gerechtigkeit. Festschrift für Hubert Rottleuthner, red. M. Mahlmann, Baden-Baden 2011.

Giezek J., [w:] Prawo karne materialne. Czesść ogólna i szczególna, red. M. Bojarski, Warszawa 2020.

Greve M., Der justitielle und rechtspolitische Umgang mit den NS-Gewaltverbrechen in den sechziger Jahren, Frankfurt am Main 2001.

Greve M., Neuere Forschungen zu NS-Prozessen: Ein Überblick, „Kritische Justiz” 1999, nr 3.

Herzberg R.D., Täterschaft und Teilnahme, München 1977.

Hünerfeld P., Mittelbare Täterschaft und Anstiftung im Kriminalstrafrecht der Bundesrepublik Deutschland, „Zeitschrift für die gesamte Strafrechtswissenschaft” 99, 1987, nr 2.

Kardas P., Teoretyczne podstawy odpowiedzialności karnej za przestepne współdziałanie, Kraków 2001.

Krämer K., Individuelle und kollektive Zurechnung im Strafrecht, Tübingen 2015.

Küpper G., Zur Abgrenzung der Täterschaftsformen, „Goltdammer“s Archiv für Strafrecht” 1998.

Lampe E.-J., Systemunrecht und Unrechtssysteme, „Zeitschrift für die gesamte Strafrechtswissenschaft" 106, 1994, $\mathrm{nr} 4$.

Murmann U., Tatherrschaft kraft Weisungsmacht, „Goltdammer‘s Archiv für Strafrecht” 1996.

Rotsch T., Anmerkung zu BGH 1 StR 453/02, „Juristische Rundschau” 2004, nr 6.

Rotsch T., Die Rechtsfigur des Täters hinter dem Täter bei der Begehung von Straftaten im Rahmen organisatorischer Machtapparate und ihre Übertragbarkeit auf wirtschaftliche Organisationsstrukturen, „Neue Zeitschrift für Strafrecht” 1998, z. 10.

Rotsch T., Neues zur Organisationsherrschaft, „Neue Zeitschrift für Strafrecht” 2005, nr 1.

Rotsch T., Tatherrschaft kraft Organisationsherrschaft?, „Zeitschrift für die gesamte Strafrechtswissenschaft" 112, 2000, nr 3.

Roxin C., Organisationsherrschaft und Tatentschlossenheit, „Zeitschrift für Internationale Strafrechtsdogmatik" 2006, z. 7.

Roxin C., Strafrecht. Allgemeiner Teil, t. 2. Besondere Erscheinungsformen der Straftat, München 2003. 
Roxin C., Straftaten im Rahmen organisatorischer Machtapparate, „Goltdammer‘s Archiv für Strafrecht" 1963.

Roxin C., Täterschaft und Tatherrschaft, Berlin-Boston 2019.

Roxin C., Zu neusten Diskussion über die Organisationsherrschaft, „Goltdammer“s Archiv für Strafrecht" 2012.

Rückerl A., NS-Verbrechen vor Gericht. Versuch einer Vergangenheitsbewältigung, Heidelberg 1982.

Schild W., Täterschaft als Tatherrschaft, Berlin-New York 1994.

Schroeder F.-Ch., Täter hinter dem Täter. Ein Beitrag zur Lehre von der mittelbaren Täterschaft, Berlin 1965.

Schulz U., Die mittelbare Täterschaft kraft Organisationsherrschaft - eine notwendige Rechtsfortbildung?, „Juristische Schulung” 1997.

Urban C., Mittelbare Täterschaft kraft Organisationsherrschaft: eine Studie zu Konzeption und Anwendbarkeit, insbesondere im Hinblick auf Wirtschaftsunternehmen, Göttingen 2004.

Werle G., Der Holocaust als Gegenstand der bundesdeutschen Strafjustiz, „Neue Juristische Wochenschrift" 1992, z. 40. 